JKKP: Jurnal Kesejahteraan Keluarga dan Pendidikan

http://doi.org/10.21009/JKKP

DOI: doi.org/10.21009/JKKP.012.04

E-ISSN: 2597-4521

\title{
Hubungan Kelekatan Orang Tua dengan Interaksi Sosial antar Teman Sebaya pada Remaja Laki-Laki di SMPN 6 J akarta
}

\author{
1) Dwi Anggi Pradipta, ${ }^{2)}$ Hamiyati, ${ }^{3)}$ Metty Muhariati \\ 1,2,3)P rogram Studi Pendidikan Kesejahteraan Keluarga, \\ Fakultas Teknik, Universitas Negeri J akarta \\ J In. Rawamangun Muka, J akarta Timur. 13220
}

\begin{abstract}
Abstrak
Penelitian ini bertujuan untuk mengetahui hubungan antara kelekatan orang tua dengan interaksi sosial antar teman sebaya pada remaja laki-laki. Penelitian dilakukan di SMPN 6 Jakarta pada bulan April-Juni 2014 dengan sampel 72 siswa. Metode penelitian yang digunakan adalah metode survey dengan pendekatan korelasional. Hasil uji prasyarat analisis data diketahui bahwa data berdistribusi normal dan terjadi terjadi linieritas regresi. Hasil penelitian menunjukkan bahwa adanya hubungan positif antara kelekatan siswa dengan orang tua terhadap interaksi sosial antar teman sebaya laki-laki yang ditunjukan denangan koefisien korelasi Pearson Product Moment sebesar 0,656. Koefisien determinasi sebesar $43,03 \%$ yang berarti bahwa interaksi sosial antar teman sebaya ditentukan oleh kelekatan orang tua dengan anak sebesar $43,03 \%$. Hasil uji regresi diperoleh persamaan regresi $Y=47,14+0,29 \times$ yang berarti bahwa setiap kenaikan kelekatan orang tua sebanyak satu satuan akan diikuti dengan kenaikan interaksi sosial teman sebaya pada remaja sebesar 0,29 pada konstanta 47,14.
\end{abstract}

Keyword: interaksi sosial, peer group, kelekatan, remaja

\section{Correlation Between Parent Attachement and Male Adolescent Peer Group Social Interaction at $6^{\text {th }}$ J akarta J unior High School}

\begin{abstract}
The purpose of the study to know about The Correlation between parents attachment with social interaction among the peers boy group in $6 \mathrm{~J}$ akarta J unior High School.The research was held for 3 months, from April 2014- J une 2014. The method of research uses survey method by doing correlation approach. The population of research used all boy students in 8th grade of $6 \mathrm{~J}$ akarta J unior High School and the sample was taken by using simple random sampling which is every member of population has a same chance to be picked as member of sample with 72 students The resulting regression equation is $\hat{Y}=47,14+$ $0,29 X$. The results of normality test error count normal distribution with $L$ hitung 0,0712 ( $L$ table 0,1044$)$. The results of the linearity test with a linear regression is calculated $F$ hitung 0,10 ( $F$ table 1,79). Hypothesis test results that test the significance of the regression is significant with $\mathrm{F}$ count 27,47 ( $\mathrm{F}$ table 3,98 ). The correlation coefficient of Pearson Product Moment generating $r_{x y}=0,656$. The results of the study and test hypotheses about the relationship, found that there is a positive relationship between parents attachment with social interaction among the peers boy group in $6 \mathrm{~J}$ akarta J unior High School. The coefficient of determination obtained for $43,03 \% 43,03 \%$ which indicates that the social interaction among peer boy group is determined by parents attachment.
\end{abstract}

Keyword: Social Interaction, Peer G roup, Attachment, Adolescent 


\section{PENDAHULUAN}

Masa remaja merupakan masa peralihan seorang individu dari anak-anak menuju dewasa. Pada masa ini, remaja mengalami perkembangan mencapai kematangan fisik, mental, sosial, dan emosional. Masa ini merupakan masa bagi seorang individu mengalami berbagai permasalahan dan sulit untuk diatasi, hal ini dapat disebabkan oleh berbagai macam sebab salah satunya yaitu karena rasa ingin lepas dari orang tua dan rasa ingin mengatasi masalahnya sendiri.

Salah satu tugas perkembangan seseorang di masa remaja yaitu perkembangan sosial. Pada masa bayi sampai anak-anak, seorang individu baru mengenal lingkungan yang kecil yaitu keluarga, ketika individu memasuki masa remaja, maka mereka akan mengenal lingkungan yang lebih luas antara lain lingkungan sekitar rumah, lingkungan sekolah, dan lingkungan lainnya. Interaksi individu pada masa ini juga semakin meningkat dengan lingkungannya dan mempengaruhi perkembangan individu tersebut. Remaja mulai berpikir untuk membebaskan diri dari lingkungan keluarga karena mereka menganggap bahwa mereka bukan lagi anak-anak yang diatur-atur oleh orang tua dan mencoba untuk mandiri.

Dewasa ini, berbagai macam kenakalan yang dilakukan oleh remaja dengan mudah dapat kita temui. Ini dapat dibuktikan dengan banyaknya muncul berita tentang kasus kenakalan remaja baik di media massa maupun media cetak. Banyak sekali faktor yang melatar belakangi mengapa remaja melakukan hal yang demikian. Teman sebaya menjadi pengaruh besar dalam perkembangan sosial pada masa remaja karena interaksi antar teman sebaya yang sering dan intens, ini dikarenakan remaja lebih banyak berada di luar rumah bersama dengan teman-teman sebayanya, sehingga pengaruh yang diberikan oleh teman sebaya lebih besar daripada pengaruh keluarga. Sebagai contoh yang penulis dapatkan dari observasi kepada beberapa remaja adalah mereka yang pada awalnya tidak merokok akhirnya ikut merokok karena melihat temannya merokok dan di bujuk untuk mencoba rokok tersebut.

Berbagai kasus kenakalan yang terjadi di kalangan remaja sangat memprihatinkan. Kasus pornografi yang terjadi di kalangan remaja menjadi sorotan peneliti. Data yang disampaikan Komisi Perlindungan Anak Indonesia (KPAI) kepada koran Tempo pada tanggal 2 november 2013 yang dikutip pada tanggal 26 Februari 2014, setidaknya ada 84 laporan pornografi dan pornoaksi hingga Oktober 2013 ini. Seluruhnya dilakukan oleh anak-anak dari kalangan pelajar dibawah umur, khususnya di Jakarta. Jumlah tersebut terdiri dari pergaulan seks bebas dan kepemilikan media pornografi, tak sedikit pula yang hamil di luar nikah. Rentang usia yang melakukan seks pranikah berkisar antara $13-18$ tahun.

Tidak hanya kasus pornografi yang menjadi masalah pada remaja saat ini, sejumlah remaja juga sudah mulai mengenal rokok. Rokok sudah menjadi sebuah tren baru remaja saat ini dan bukan lagi menjadi sesuatu yang harus dijauhi, hal ini di buktikan dengan banyaknya di temukan di tempat- tempat umum pelajar yang masih mengenakan baju seragam dengan memegang rokok di tangan mereka. Menurut liputan6.com yang dikutip pada tanggal 21 Februari 2014, remaja Indonesia yang merokok terbilang tinggi. Bahkan, anak-anak yang menjadi perokok pemula jumlahnya terus meningkat dalam 10 tahun terakhir. Jumlah perokok pemula yakni usia 10-14 tahun naik dua kali lipat dari 9,5 persen pada 2001 menjadi 17,5 persen pada tahun 2010.

Sementara dari Data Riskesdas 2010, di kalangan remaja 15-19 tahun sebesar 38,4 persen laki-laki dan 0,9 persen perempuan yang merokok. Sedangkan menurut data Global Youth Tobacco Survey (GYTS) 2009 yang masih dikutip melalui media online liputan6.com, menunjukkan bahwa 20,3\% anak sekolah 13-15 tahun merokok. Selain seks bebas dan merokok, hal yang tidak kalah memprihatinkan adalah makin banyaknya kasus tawuran yang terjadi antar siswa SMP. Menurut data Komisi Perlindungan Anak Indonesia (KPAl) yang dikutip dari media online tribunnews.com bahwa Kasus tawuran pelajar di Jakarta terus meningkat. Sepanjang tahun 2013 ini terjadi 112 kasus dengan menewaskan 12 siswa. Kasus tawuran pelajar di DKI Jakarta sebanyak 112 kasus pada 2013 juga mengalami peningkatan dibanding 
tahun 2012 yakni 98 kasus. Salah satu kasus yang penulis temukan di situs kompas.com adalah kasus tawuran yang terjadi antara siswa SMPN 6 dengan sekolah lain sehingga menyebabkan salah satu murid di SMPN 6 tersebut meninggal dunia akibat ditabrak kereta pada saat tawuran. Hal inilah yang melatar belakangi penulis untuk mengadakan penelitian di SMPN 6 Jakarta.

Dari berbagai kasus di atas, salah satu faktor penyebabnya adalah kurangnya interaksi dalam keluarga. Lingkungan pertama yang berhubungan dengan anak adalah keluarga. Hubungan anak dengan orang tua merupakan sumber emosional dan kognitif bagi anak. Hubungan tersebut memberi kesempatan bagi anak untukmengeksplorasi lingkungan maupun kehidupan sosial. Melalui lingkungan itulah anak mengenal dunia sekitarnya dan pola pergaulan hidup yang berlaku sehari-hari. Lemahnya pengawasan orang terdekat juga merupakan salah satu problem yang harus dibenahi, akibat proses pengawasan terhadap anak yang tidak maksimal ini, anak bisa melakukan apa yang dia mau tanpa ada batasan.

Orang tua sebagai pengasuh utama anak memegang peranan penting dalam penentuan status kelakatan anak, apakah anak akan membentuk kelekatan aman atau sebaliknya. Kelekatan merupakan suatu ikatan emosional yang kuat yang dikembangkan anak melalui interaksinya dengan orang yang mempunyai arti khusus dalam kehidupannya yaitu orang tua. Anak yang memiliki kelekatan aman akan menunjukkan tingkah laku yang baik karena dia merasa bahwa ada yang melindungi, menyayangi dan tempat berbagi. Sebaliknya pengasuh yang tidak menyenangkan akan membuat anak tidak percaya dan mengembangkan kelekatan yang tidak aman. Kelekatan yang tidak aman dapat membuat anak mengalami berbagai permasalahan yang salah satunya adalah kenakalan dan pergaulan bebas. Jadi dapat dismpulkan bahwa gangguan kelekatan terjadi karena anak gagal membentuk kelekatan yang aman dengan figur lekatnya yaitu orangtua. Hal ini akan membuat anak mengalami masalah dalam hubungan sosial.

Berdasarkan latar belakang masalah diatas, maka peneliti tertarik untuk meneliti hubungan antara kelekatan orang tua dengan interaksi sosial antar teman sebaya pada remaja laki-laki di SMPN 6 Jakarta.Banyaknya permasalahan yang telah diidentifikasi, maka perlu membatasi ruang lingkup masalah penelitian mengingat terbatasnya waktu penelitian pada hubungan kelekatan orang tua dengan interaksi sosial antar teman sebaya pada remaja laki- laki di SMPN 6 Jakarta.

Berdasarkan identifikasi dan pembatasan masalah, maka dapat dirumuskan "Apakah terdapat hubungan antara kelekatan orang tua dengan interaksi sosial antar teman sebaya pada remaja?"

Tujuan dari penelitian ini adalah untuk dapat mengetahui hubungan kelekatan orang tua dengan interaksi sosial antar teman sebaya pada remaja laki- laki di SMPN 6 Jakarta.

Penelitian yang dilakukan mempunyai beberapa kegunaan antara lain untuk; (1) Memperkaya bahan ajar bagi mata kuliah teori keluarga; (2) Memotivasi mahasiswa program studi Pendidikan Kesejahteraan Keluarga IKK-FT-UNJ untuk melakukan penelitian lebih lanjut mengenai kelekatan orang tua dengan remaja berdasarkan faktor lainnya; (3) Memotivasi mahasiswa program Studi Pendidikan Kesejahateraan Keluarga IKK-FT-UNJ untuk melakukan penelitian lebih lanjut mengenai pengaruh teman sebaya terhadap perkembangan remaja; (4) Orang tua semakin mengerti bahwa kelekatan sangat berpengaruh terhadap interaksi sosial antar teman sebaya pada remaja; (5) Anak semakin mengerti bahwa kelekatan dengan orang tua sangat berperan terhadap perkembangan sosial terutama dengan interaksi teman sebaya.

\section{METODE PENELITIAN}

Penelitian ini dilakukan di Sekolah Menengah Pertama Negeri (SMPN) 6 Jakarta yang beralamatkan di Jl. Bulak Timur 1, Klender, Kotamadya Jakarta Timur, Jakarta. Waktu penelitian dilakukan selama 3 bulan terhitung dari April- Juni 2014.

Metode yang digunakan dalam penelitian ini adalah survei dengan pendekatan korelasional. Populasi adalah wilayah generalisasi yang terdiri atas: objek atau subjek yang mempunyai kualitas 
dan karakteristik tertentu yang ditetapkan oleh peneliti. Populasi penelitian ini adalah seluruh siswa laki-laki kelas VIII SMPN 6 Jakarta yang berjumlah 88 orang. Sampel adalah bagian dari jumlah dan karakteristik yang dimiliki oleh populasi (Sugiono, 2008: 81). Sampel dalam penelitian ini adalah siswa laki-laki kelas VIII SMPN 6 Jakarta yang masih memiliki orang tua baik ayah maupun ibu dan tinggal bersama yang berjumlah 72 orang.

Teknik yang digunakan dalam menentukan sampel yaitu dengan menggunakan teknik simple random sampling (teknik acak sederhana). Teknik acak sederhana (simple random sampling) adalah metode pemilihan ukuran sampel di mana setiap anggota populasi mempunyai peluang yang sama untuk di pilih menjadi anggota sampel (Arikunto, 2010: 177).

\section{HASIL DAN PEMBAHASAN}

Data kelekatan orang tua (Variabel $\mathrm{X}$ ) diperoleh melalui pengisian instrument penelitian berupa kuesioner yang diisi oleh 72 siswa laki-lakiSMP N 6 Jakarta. Data yang dihasilkan memiliki skor terendah 109 dan skor tertinggi 180 , skor rata-rata $(X)$ sebesar 148,74 varians $\left(S^{2}\right)$ sebesar 310,65 dan simpangan baku (S) sebesar 17,63.

\section{a. Kelekatan Dalam Bentuk Orang Tua Membantu dan Menolong Anak}

Dari hasil penelitian menunjukkan bahwa orang tua membantu dan menolong menjadi penyumbang persentase terbesar dibanding sub indikator yang lain. Dari hasil penelitian orang tua siswa laki-laki di SMPN 6 Jakarta sangat membantu dan menolong anak-anaknya dalam berbagai permasalahan. Ini tergambar di dalam pernyataan yang peneliti ajukan, bahwa siswa laki-laki di SMPN 6 selalu menceritakan dan mencari bantuan kepada orang tua dibandingkan kepada orang lain dari mereka kecil hingga sekarang di saat mereka ada masalah. Perasaan tertekan akan dirasakan oleh mereka apabila harus menghadapi permasalahannya sendiri tanpa dibantu oleh orang tua. Selain mereka meminta orang tua untuk membantu menyelesaikan semua kesulitan yang mereka hadapi, orang tua juga tidak segan untuk menawarkan bantuan dan menanyakan permasalahan apa yang sedang mereka alami.

\section{b. Pendampingan Orang Tua Terhadap Anak}

Sub indikator ini menyumbang persentase terbanyak kedua setelah orang tua membantu dan menolong. Dampingan orang tua sangat berperan penting dalam perkembangan anak-anak menuju remaja. Pada penelitian di SMPN 6 terlihat bahwa mereka merasa aman berada di dekat orang tua dan mereka akan cemas bila berada jauh dengan orang tuanya. Orang tua memang seharusnya bisa memberikan rasa aman terhadap anak-anaknya sehingga mereka akan lebih senang berada di rumah dan dapat terhindar dari kemungkinan melakukan tindak kenakalan.

\section{c. Orang Tua Responsif}

Orang tua responsif merupakan orang tua yang cepat dan tanggap terhadap segala kemungkinan yang terjadi terhadap anak- anaknya. Siswa laki-laki di SMPN 6 merasakan bahwa orang tua mereka cukup responsif terhadap mereka. Hal ini terlihat dari jawaban terhadap pernyataan yang peneliti ajukan. Orang tua mereka sangat tertarik terhadap permasalahanpermasalahan yang mereka hadapi dengan penuh rasa perhatian dan dengan senang hati mendengarkan segala permasalahan-permasalahan tersebut.

\section{d. Orang Tua Penuh Cinta dan Kasih Sayang}

Sub indikator keempat yang juga tidak kalah pentingnya yaitu orang tua yang penuh cinta dan kasih sayang terhadap anak-anaknya. Tentu saja anak-anak yang sedang dalam masa peralihan sangat membutuhkan cinta dan kasih dari orang tuanya. Ini juga yang dirasakan oleh siswa laki-laki di SMPN 6 bahwa orang tua yang penuh cinta dan kasih saying sangat 
membantu mereka dalam perkembangannya. Siswa laki-laki di SMPN 6 merasa nyaman berada di dekat orang tua baik untuk menyampaikan pendapat ataupun melakukan aktivitas-aktivitas bersama orang tua karena orang tua mereka penuh kepedulian terhadap mereka.

\section{e. Orang Tua Sensitif}

Sub indikator ini menjadi sub indikator penyumbang persentase terkecil dari yang ainnya. Orang tua sensitif merupakan orang tua yang peka terhadap anak-anaknya. Sensitivitas orang tua dengan siswa laki-laki SMPN 6 bisa dikategorikan cukup baik. Siswa laki-laki di SMPN 6 merasakan bahwa orang tua dapat memahami dan memperhatikan segala tindakantindakan ataupun keinginan- keinginan mereka.

Data interkasi sosial (Variabel Y) diperoleh melalui pengisian instrument penelitian berupa kuesioner yang diisi oleh 72 siswa laki-laki SMP N 6 sebagai Responden dengan teknik pengambilan sampling menggunakan simple random sampling (sampel acak sederhana) Data yang dihasilkan memiliki skor terendah 76 dan skor tertinggi 106, skor rata-rata (X) sebesar 89,588, varians (S2) sebesar 58,84 dan simpangan baku (S) sebesar 7,67.

\section{a. Kontak Sosial}

Pada penelitian ini, indikator kontak sosial menjadi penyumbang terbesar diantara variabel yang lainnya. Kontak sosial merupakan hubungan yang terjadi antara satu individu dengan individu lain. Soekanto (2001: 71) mendeskripsikan kontak sosial menjadi tiga bagian yaitu; (1) Kontak yang terjadi antara orang-perorangan; (2) Kontak orang perorangan dengan kelompok atau sebaliknya; (3) Kontak antara kelompok dengan kelompok. Kontak sosial yang terjadi diantara siswa laki-laki SMPN 6 Jakarta dalam lingkup yang positif. Hal ini tergambar di dalam jawaban pernyataan yang peneliti ajukan bahwa siswa laki-laki di SMPN 6 mengahabiskan waktu istirahat mereka bersama teman sebayanya dan saling bertukar ide. Selain itu, di dalam kelas mereka saling berdiskusi pelajaran dengan teman-temanya dan mengerjakan tugas kelompok bersama-sama.

\section{b. Komunikasi}

Komunikasi merupakan proses penyampaian informasi dari satu orang ke orang lain sehingga informasi tersebut dapat dipahami dan dimengerti. Menurut Soekanto (2001: 67), arti penting komunikasi adalah bahwa seseorang memberikan tafsiran pada perilaku orang lain (yang berwujud pembicaraan, gerak gerik badaniah, atau sikap), perasaan-perasaan apa yang ingin disampaikan oleh orang tersebut. Dalam penelitian ini, komunikasi antara siswa laki-laki SMPN 6 dengan teman sebayanya tergolong baik. Hal ini digambarkan dalam jawaban pernyataan yang peneliti berikan dimana siswa laki-laki di SMPN 6 tidak suka mengikuti gaya temannya dalam berpenampilan serta tidak ikut dengan temannya untuk keluar malam. Ini merupakan sikap positif yang dihasilkan antara siswa SMPN 6. Selain sikap, pembicaraan pun juga masih sehubungan dengan lingkungan sekolah seperti pelajaran dan pekerjaan rumah.

\section{c. Maksud atau Tujuan yang Jelas}

Indikator ini merupakan penyumbang terkecil pada variabel interaksi sosial. Tingkah laku kelompok sangat berpengaruh di dalam interaksi sosial karena tingkah laku dari suatu kelompok dapat mempengaruhi bahkan mengubah tingkah laku individu atau kelompok lainnya. Walgito (2000: 17) mendeskripsikan bahwa tingkah laku individu dapat mempengaruhi individu itu sendiri, maupun berpengaruh pada lingkungan, demikian pula lingkungan dapat mempengaruhi individu dan sebaliknya. Pengaruh teman sebaya dalam interaksi laki-laki di SMPN 6 dalam penelitian ini cukup positif. Hal ini tergambar bahwa siswa laki-laki di SMPN 6 dapat berperilaku positif karena ajakan teman seperti tidak bolos sekolah, membuang sampah pada tempatnya, dan ke perpustakaan bersama-sama untuk mengerjakan tugas. Jadi dapat disimpulkan bahwa teman 
sebaya pada remaja tidak selalu menyebabkan seseorang untuk berbuat negatif.

Dari hasil perhitungan penelitian ini, diperoleh rhitung $\left(r_{x y}\right)$ sebesar 0,656 . Ini menunjukkan $r_{x y}>0$, sehingga dapat disimpulkan antara kelekatan orang tua dengan interaksi sosial antar teman sebaya pada remaja di SMPN 6 Jakarta terdapat hubungan yang positif.

Uji keberartian (signifikasi) koefisien korelasi dilakukan untuk mengetahui apakah hubungan antara kelekatan orang tua dengan interaksi sosial antar teman sebaya signifikan atau tidak, maka selanjutnya dilakukan uji keberartian korelasi dengan menggunakan Uji- t pada taraf signifikan $\alpha=0,05$ dengan $\mathrm{dk}=\mathrm{n}-2$. Kriteria pengujiannya adalah $\mathrm{H}_{0}$ ditolak apabila thitung $>$ ttabel, maka korelasi yang terjadi signifikan. Data hasil perhitungan menunjukkan thitung sebesar 5,093 dan ttabel sebesar 1,66. Karena thitung $(5,093)>$ ttabel $(1,66)$, maka dapat disimpulkan antara kelekatan orang tua dengan interaksi sosial antar teman sebaya terjadi korelasi yang signifikan. Besarnya derajat hubungan kedua variabel dapat dilihat dari besarnya angka koefisien determinasi yaitu sebesar $43,03 \%$. Koefisien determinasi antara hubungan kelekatan orang tua $(\mathrm{X})$ terhadap interaksi sosial antar teman sebaya $(\mathrm{Y})$ sebesar $0,656^{2}=$ 0,4303 atau berarti $43,03 \%$.

Selanjutnya dicari persamaan regresi untuk mengetahui hubungan antara kelekatan orang tua dengan interaksi sosial antar teman sebaya laki-laki di SMPN 6 Jakarta. Analisis regresi linier data penelitian kelekatan orang tua dengan interaksi sosial antar teman sebaya menghasilkan arah regresi sebesar 0,29 dan konstanta sebesar 47,14. Dengan demikian bentuk hubungan antara kelekatan orang tua dengan interaksi sosial antar teman sebaya mempunyai persamaan regresi $\hat{Y}=47,14+0,29 X$. Pengujian keberartian regresi dilakukan dengan kriteria pengujian regresi berarti (signifikan) apabila Fhitung $>$ Ftabel yang artinya Ho ditolak, dan dapat dibuktikan dengan hasil perhitungan Fhitung $=27,47$ sedangkan Ftabel $=3,98$. Ini berarti Fhitung > Ftabel, maka pengujian hipotesis statistiknya adalah Ho ditolak, yang berarti persamaan regresi adalah signifikan.

\section{KESIMPULAN}

Berdasarkan pengolahan deskriptif, analisis, interpretasi data dan pengolahan data statistik yang telah diuraikan pada bab - bab sebelumnya maka dapat disimpulkan bahwa:

1. Hasil perhitungan koefisien determinasi sebanyak $43,03 \%$ yang artinya $43,03 \%$ interaksi sosial siswa laki-laki SMPN 6 Jakarta ditentukan oleh kelekatan dengan orang tua dan $56,97 \%$ sisanya ditentukan oleh faktor lain.

2. Hasil hipotesis penelitian dan uji mengenai hubungan, diperoleh bahwa terdapat hubungan yang positif antara hubungan kelekatan orang tua dengan interaksi sosial antar teman sebaya pada remaja di SMP N 6 Jakarta.

\section{DAFTAR PUSTAKA}

Ainsworth, M. D. S. 1989. Attachment Benyond Infancy. The american Psychological Association Vol 44 No 4, 709-716. http://psycnet.apa.org 16 April 2014.

Ahmad, Abu, 2002. Psikologi Sosial. Jakarta: Rineka Cipta

Ali, Muhammad dan Asrori, Muhammad. 2005. Psikologi Remaja. Jakarta: Bumi Aksara.

Arikunto, Suharsimi. 2010. Prosedur P enelitian Suatu Pendekatan Praktik. Jakarta: Rineka Cipta.

Baron, Roberta, A., \& Byrne, Donn. 2003. Psikologi Sosial. Jilid 2. (terjemahan Ratna Djuwita, dkk,). Jakarta: Erlangga

Bee, Helen. 2000. The Developing Child. Massachusetts: Allyn Bacon

Collins, N. L. \& Read, S. 1990. Adult Attachment, Working Model, and Relationship Quality in Dating Couples. Journal Personality and Social Psychology. American Psychological 
Association, Inc. 58, 4: $644-663$

Crain, William. 2007. Teori Perkembangan: Konsep dan Aplikasi. Edisi ketiga. Yogyakarta: Pustaka Pelajar.

Desmita. 2006. Psikologi Perkembangan, Cetakan ke-2. Bandung: PT. Remaja Rosdakarya.

Djaali dan Muljono, P. 2011. Pengukuran Dalam Bidang Pendidikan. Jakarta: PT Grasindo.

Effendi, Sofian. 2012. Metode Penelitian Survey. Jakarta: LP3ES

Erwin, Phil. 1998. Friendship in Childhood and Adolescene. London: Routledge. Gerungan. 2000. Psikologi Sosial. Jakarta: PT. Eresco. 2009. Psikologi Sosial. Bandung: Refika Adi Tama.

Hazan, Cindy \& Shaver, Phillip. 1987. Romantic Love Conceptualizad as an Attachment Process. Journal Personality and Social Psychology. American Psychological Assosiation, Inc. 52, 3: $511-524$.

Hurlock, Elizabeth. B. 2004. Psikologi Perkembangan: Suatu Pendekatan Sepanjang Rentang Kehidupan (Terjemahan Instiwidayanti dan Soedjarwo). Edisi Kelima. Jakarta: Erlangga.

Kuswanto, Dedy. 2012. S tatistik Untuk Pemula dan Orang. Jakarta: Laskar Aksara

Febrida Melly. 2013. Perokok Usia 10 Tahun di Indonesia Meningkat. http://health.liputan6.com/read/743251/perokok-usia-10-tahun-di-indonesia jumlahnyameningkat. 26 Maret 2014

Mappiare, Andy. 1982. Psikologi Remaja. Surabaya: Usaha Nasional

Mc Cartney, Kathleen. \& Dearing, Eric., (Ed). 2002. Child Development. Mc Millan Refference USA.

Newcomb, Theodore \& Converse, Philip. 1985. Social Psichology. New York: Sage Publication, Ltd.

Papalia, D. E., Old, S. W., Feldman, \& R. D. 2008. Human Development (terjemahan A. K. Anwar). Jakarta: Prenada Media Group.

Parke, Rose. D \& Gauvain, Mary. 2009. Child psychology a cotemporary viewpoint seventh edition. New york: Mc Graw Hill. Paterson. Candida. 1989. looking forward throught the life span developmental psychology second edition. New York: Prentice Hall.

Rahman, Dias, T dkk. 2000. Panduan Belajar Sosiologi. Bogor: Yudhistira.

Santoso, Santosa. 1999. Dinamika Kelompok Sosial. Jakarta: Bumi Aksara.

Santrock, John. W. 2002. Life S pan Development Eight Edition. New york: Mc Graw Hill. . 2003. Adolescence Perkembangan Remaja (Terjemahan Adelar, S. B. \& Saragih, S). Jakarta: Erlangga.

Sarwono, Sarlito. W. 1999. Psikologi Sosial. Jakarta: Balai Pustaka.

Soekanto, Soerjono. 2001. Sosiologi Suatu Pengantar. Jakarta: Raja Grafindo Persada.

Sudjana. 2005. Metode Statistika. Bandung: Tarsito

Sugiono. 2005. Metode Administrasi. Bandung: Alfabeta

. 2008. Metode Penelitian Kuantitatif, Kualitatif dan R\&D. Bandung: PT Refika Aditama.

Addhiya. 2013. Awas Pergaulan Bebas. http://geraipinpalangkaraya.blogspot.co m/2013 /12/awaspergaulan-bebas- menyerangremaja. html. 26 Maret 2014.

Aji. Wahyu. 2013. Kasus Tawuran Pelajar Jakarta Terus Meningkat Tahun Ini. http://www.tribunnews.com/metropolita n/2013 /12/22/kasus-tawuran-pelajar- jakartaterusmeningkat- tahun-ini. 26 Maret 2014.

Vembriarto. 1993. Sosiologi Pendidikan. Jakarta: Gramedia.

Walgito, Bimo. 2003. Psikologi Sosial (Suatu Pengantar). Yogyakarta: Andi Offset. Yessy. 2003. Hubungan Pola Attachment dengan Kemampuan Menjalin Relasi Pertemanan pada Remaja. J urnal Psikologi. 12, 2: 1-12 